\title{
The Relationship of Diarrhea in COVID-19 Patients With Transaminitis, Severity, and Mortality
}

\author{
Amanda C Wowor*, Supriono**, Bogi Pratomo**, Syifa Mustika ${ }^{* *}$ \\ *Department of Internal Medicine, Faculty of Medicine, Universitas Brawijaya, Malang \\ ** Division of Gastroentero-hepatology, Department of Internal Medicine, \\ Universitas Brawijaya/Dr. Saiful Anwar Hospital, Malang
}

\section{Corresponding author:}

Amanda C Wowor. Department of Internal Medicine, Faculty of Medicine, Universitas Brawijaya Malang. Jl. Jaksa Agung Suprapto No. 2 Malang.Phonelfacsimile:+62-341-348265.Email: amandawowor89@gmail.com

\begin{abstract}
Background: Coronavirus disease 2019 (COVID-19) is a pandemic that causes various types of symptoms. Diarrhea is a gastrointestinal symptom that is hypothesized to be associated with patient morbidity and mortality. Research on the relationship between diarrhea and the incidence of transaminitis, severity and mortality has never been carried out, so further research is needed

Method: Descriptive-analytic research design with a case-control study approach. Sampling using consecutive sampling on patients in the inpatient installation of dr. Saiful Anwar, Malang. Research data on diarrhea incidence, transaminitis, severity, and mortality were obtained from secondary data on COVID-19 patients. Data were analyzed using chi-square with a significance level $p<0.05$

Results: The incidence of diarrhea in COVID-19 patients with transaminitis was $45.8 \%$ and significantly associated $(p=0.025)$. Diarrhea in COVID-19 patients was associated with severity $(p=0.046)$ and patient mortality $(p=0.028)$.

Conclusion: There is a relationship between the incidence of diarrhea in COVID-19 patients with trasnsaminitis, severity and mortality
\end{abstract}

Keywords: COVID-19, diarrhea, transaminitis, severity, mortality, relationships

\begin{abstract}
ABSTRAK
Latar belakang: Coronavirus disease 2019 (COVID-19) adalah pandemi yang menimbulkan berbagai jenis gejala. Diare adalah gejala gastrointestinal yang diduga berhubungan dengan morbiditas dan mortalitas pasien. Penelitian hubungan diare dengan kejadian transaminitis, severitas, dan mortalitas belum pernah dilakukan sehingga perlu penelitian lebih lanjut

Metode: Desain penelitian deskriptif-analitik dengan pendekatan case-control study. Pengambilan sampel menggunakan consecutive sampling pada pasien di instalasi rawat inap RSUD dr. Saiful Anwar, Malang. Data penelitian tentang kejadina diare, transaminitis, severitas, dan mortalitas didapatkan dari data sekunder pasien COVID-19. Data dianalisa menggunakan chi-square dengan tingkat signifikasi $p<0,05$.

Hasil: kejadian diare pada pasien COVID-19 dengan transaminitis sebesar 45,8\% dan berhubungan signifikan ( $p$ =0,025). Diare pada pasien COVID-19 berhubungan dengan severitas $(p=0,046)$ dan mortalitas pasien $(p=0,028)$

Simpulan: Terdapat hubungan antara kejadian diare pada pasien COVID-19 dengan Peningkatan Transaminase, severitas, dan mortalitas
\end{abstract}

Kata kunci: COVID-19, diare, transaminitis, severitas, mortalitas, hubungan 


\section{INTRODUCTION}

Coronavirus disease 2019 (COVID-19) caused by the severe acute respiratory syndrome coronavirus 2 (SARS-CoV-2) has become a global pandemic. Based on the WHO report, the world prevalence reached 719,758 confirmed cases with 33,673 in March 2020. ${ }^{1}$ The prevalence of COVID-19 increased to 42 million confirmed cases and more than 1.1 million deaths in October $2020 .^{2}$ SARS-CoV-2 infection can occur asymptomatic or symptomatically with a wide spectrum of manifestations. ${ }^{3}$

Gastrointestinal manifestations in COVID-19 patients have an incidence rate of $16-50 \%$ of all COVID-19 patients. ${ }^{4}$ Diarrhea is the most common manifestation in patients with COVID-19. ${ }^{3}$ The pathophysiology of diarrhea is caused by invasion of the SARS-CoV-2 virus in the intestines, thereby increasing its permeability and inhibits the absorption of enterocytes. ${ }^{3}$ In addition, intestinal disturbances alter the microbes in the gut and increase proinflammatory cytokines which can worsen the patient's condition. ${ }^{5}$ The incidence of diarrhea is known to worsen the prognosis of COVID-19 patients. $^{6}$ Severe symptomatic COVID-19 patients with diarrhea require a longer hospital stay, mechanical ventilation, and ICU use. The mortality rate for COVID-19 patients with diarrhea symptoms is estimated to be $1-4 \%$ and increases to $32 \%$ in patients with severe symptoms. ${ }^{7}$ Identification of diarrhea symptoms in COVID-19 patients is important to prevent mortality and reduce the severity of COVID-19 patients.

Apart from worsening the patient's prognosis, diarrhea symptoms are also known to increase the transaminase enzyme so that patients develop transaminitis. A systematic review by Puli et al (2020) shows that diarrhea symptoms are associated with increased levels of the transaminase enzyme. ${ }^{8}$ Another study by Hao et al (2020) has shown that patients with elevated transaminase enzymes mostly have diarrhea symptoms. in Indonesia so that further research is needed on the relationship between diarrhea symptoms and transaminitis, especially in Indonesia. Research on the incidence of diarrhea against transaminitis, severity and mortality of COVID-19 patients has never been carried out. Therefore, further research is needed on the relationship between the incidence of diarrhea and the severity and mortality of COVID-19 patients.

\section{METHOD}

This research method is case control observational. The control group in this study was COVID-19 patients who did not experience diarrhea. The sampling method in this study was purposive sampling. The study was conducted in the inpatient room of dr. Saiful Anwar Malang by taking data on COVID-19 patients treated by the Department of Internal Medicine from 1 August 2020 to 31 October 2020. The research sample was part of the population that met the inclusion criteria and did not meet the exclusion criteria. The inclusion criteria of the subjects consisted of inpatients who were confirmed SARS-CoV-2 through the real-time polymerase chain reaction examination. The exclusion criteria were hospitalized patients who were confirmed SARS-CoV-2 through rapid antigen and antibody tests. Transaminitis was defined by an increase in aspartate aminotransferase (AST) $(>40 \mu / \mathrm{L})$ and alanine aminotransferase (ALT) $(>56 \mu / \mathrm{L})$ at least once laboratory testing. Severity was defined by Indonesian COVID-19 treatment guideline.

\section{RESULTS}

The sample characteristics in this study are listed in Table 1

\begin{tabular}{ll}
\multicolumn{2}{c}{ Table 1. Sample characteristics } \\
\hline Characteristic & $\mathbf{n}(\%)$ \\
\hline Sex & \\
$\quad$ Male & $12(50)$ \\
$\quad$ Female & $12(50)$ \\
Years & \\
$\leq 40$ & $4(16.7)$ \\
$41-60$ & $16(66.7)$ \\
$\geq 61$ & $4(16.7)$ \\
COVID-19 severity & $10(41.7)$ \\
$\quad$ Mild & $10(41.7)$ \\
$\quad$ Moderate & $1(4.2)$ \\
Severe & $3(12.5)$ \\
Critical & \\
Patient Mortality & $20(83.3)$ \\
Discharge & $4(16.7)$ \\
Death &
\end{tabular}

Based on the results presented in Table 1, it shows that the sex of the study sample consisted of 12 men $(50 \%)$ and 12 women (50\%). Most of the age of the sample in this study were $41-60$ years with a percentage of $66.7 \%$. In this study, most of the COVID-19 patients used as the study sample had moderate and mild degrees respectively $41.7 \%$. The percentage of patient mortality in this study was $16.7 \%$.

The relationship between the incidence of diarrhea and transaminitis in sufferers of COVID-19 is shown in Table 2

The results in Table 2 show that most of the patients did not experience diarrhea and had transaminitis (45.8\%). A small proportion of patients did not experience diarrhea and did not experience transaminitis 
Table 2. The relationship between diarrhea and transaminitis in COVID-19 Patients

\begin{tabular}{lccccc}
\hline \multirow{2}{*}{ Variable } & & \multicolumn{2}{c}{ Diarrhea } & \multirow{2}{*}{ p } & OR \\
\cline { 2 - 4 } & & No & Yes & & \\
\hline \multirow{2}{*}{ Transaminitis } & Yes & $\begin{array}{c}11(45,8 \%) \\
1(4,2 \%)\end{array}$ & $\begin{array}{r}6(25,0 \%) \\
6(25,0 \%)\end{array}$ & 0,025 & 11,00 \\
\hline
\end{tabular}

(4.2\%). Based on the chi-quare analysis, it shows that there is a significant relationship between the incidence of diarrhea and transaminitis in COVID-19 patients ( $\mathrm{p}$ $<0.05$ ). The odds ratio of 11.00 indicates that patients with diarrhea symptoms are 11 times more likely to experience transaminitis than those without diarrhea.

The relationship between the incidence of diarrhea and the degree of COVID-19 in this study is shown in Table 3.

Table 3. The relationship between diarrhea and the degree of COVID-19

\begin{tabular}{|c|c|c|c|c|c|}
\hline \multirow{2}{*}{\multicolumn{2}{|c|}{ Variable }} & \multicolumn{2}{|c|}{ Diarrhea } & \multirow[b]{2}{*}{ p } & \multirow[b]{2}{*}{ OR } \\
\hline & & $\begin{array}{c}\text { No } \\
\text { n (\%) }\end{array}$ & $\begin{array}{c}\text { Yes } \\
\text { n (\%) }\end{array}$ & & \\
\hline \multirow{4}{*}{ Severity } & Mild & $8(33.3)$ & $2(8.3)$ & \multirow{4}{*}{0,046} & \multirow{4}{*}{0,7} \\
\hline & Moderate & $4(16.7)$ & $6(25.0)$ & & \\
\hline & Severe & 0 (0) & $1(4.2)$ & & \\
\hline & Critical & $0(0)$ & $3(12.5)$ & & \\
\hline
\end{tabular}

The results in table 3 show that most of the patients did not experience diarrhea and suffered from a mild degree of COVID-19 (33.3\%). A small proportion of patients have severe and critical degrees of COVID-19 without any incidence of diarrhea $(0 \%)$. The results of the chi-quare analysis showed that there was a significant relationship between the incidence of diarrhea and the degree of COVID-19 ( $<<0.05)$. The odd ratio value of 0.7 shows that patients with symptoms of diarrhea have a 0.7 times chance of experiencing severe and critical COVID-19 than those without diarrhea.

Chi-square analysis of the incidence of diarrhea and mortality of COVID-19 patients in this study is shown in Table 4.

Table 4. Relationship between diarrhea and mortality in COVID-19 patients

\begin{tabular}{|c|c|c|c|c|c|}
\hline \multirow[b]{2}{*}{ Variable } & & \multicolumn{2}{|c|}{ Diarrhea } & \multirow[b]{2}{*}{ p } & \multirow[b]{2}{*}{ OR } \\
\hline & & $\begin{array}{l}\text { No } \\
\text { n (\%) }\end{array}$ & $\begin{array}{l}\text { Yes } \\
\text { n (\%) }\end{array}$ & & \\
\hline Mortality & Discharge & $12(50)$ & $8(33.3)$ & 0,028 & 13,23 \\
\hline
\end{tabular}

The results in table 4 show that most of the patients did not experience diarrhea and were discharged from the hospital (50\%). A small proportion of patients had no diarrhea and died $(0 \%)$. Based on the chi-quare test, it shows a $p$-value of $p<0.05$, which proves that there is a significant relationship between the incidence of diarrhea and the mortality of COVID-19 patients $(p<0.05)$. The odd ratio value of 13.23 shows that patients with symptoms of diarrhea have a 13.23 times chance of dying compared to those without symptoms of diarrhea.

\section{DISCUSSION}

Based on the results of the study, the sample used was 24 people with a presentation of $50 \%$ male and $50 \%$ female. Previous studies have shown that men have a higher risk of being infected with COVID-19, including its incidence severity. ${ }^{10}$ This is thought to be due to several factors that exist in men such as more ACE-2 receptors (angiotensin converting enzyme 2), less number of $\mathrm{X}$ chromosomes that play a role in the immune system and immunosuppressive properties of the sex hormone testosterone. ${ }^{11}$ However, based on epidemiological data, More diagnosed cases of COVID-19 were hospitalized in women. ${ }^{12}$ The age of the most research sample was in the range of 41-60 years with a percentage of $66.7 \%$. Patients diagnosed with COVID-19 were found mostly in middle age, namely around $47-56$ years. ${ }^{13}$ The degrees obtained in the study sample with the highest percentage of $41.7 \%$ were mild and moderate degrees. Research by $\mathrm{Wu}$ et al (2020) explained that as many as $81 \%$ of COVID-19 patients mostly had mild or moderate symptoms, $14 \%$ had severe symptoms and 5\% had critical illness. Mortality cases in this study included $16.7 \%$ as many as 4 people. The death rate for COVID-19 due to worsening symptoms is usually due to various factors. The condition of patients with older age and the presence of congenital diseases are the main factors increasing the fatality and mortality rates of COVID-19. ${ }^{14}$

In this study, transaminitis was associated with the incidence of diarrhea in COVID-19 patients (Table 5.2). In COVID-19 patients, there was an increase in the level of mild to moderate liver damage with evidence of increased levels of bilirubin, aminotransferase, and hypoproteinemia. ${ }^{15}$ According to a study by Yang et al (2020), showing that in COVID-19 patients, liver damage occurs with increasing levels alanine aminotransferase (ALT) amounted to 5.3-28.3\%. Aspartate aminotransferase (AST) and bilirubin levels also increased by $4.2-35.4 \%$ and $10.5-23.2 \%$. Patients with severe COVID-19 symptoms also experienced an increase in liver function impairment. ${ }^{16}$ Some of these patients experienced gastrointestinal disorders with diarrhea being the most common symptom. Disorders of the gut-liver axis in diarrhea are associated with 
viral infections that reduce amino acid regulation and decreased nutrient absorption. The decrease in the amount of albumin or protein in the body will make the liver to break down excess protein through hepatocyte cells so that the aminotransferase levels increase. In addition, in COVID-19 infection, the SAR-CoV-2 virus will bind to the ACE2 receptor which is also expressed in cholangiocytes and hepatocytes. Liver. This binding will cause a storm of inflammation so that many liver cells, especially cholangiocytes are damaged and transaminitis and damage to the biliary duct occurs. ${ }^{17}$ The mycobacterial imbalance of the intestine in diarrhea will also affect the gut-liver axis (portal vein), causing infection of the liver cells and inducing immune cells resulting in inflammatory reactions and liver damage. ${ }^{18}$ The mechanism of liver cell damage in covid19 patients is still not clear. Apart from the aforementioned mechanism, the use of the "an covid19 drug" can also trigger liver cell damage. ${ }^{18}$

In the sample, $25 \%$ of patients with moderate severity experience symptoms of diarrhea. Several studies presented by Ghimire et al (2021) show that during the outbreak there is an increase in gastrointestinal symptoms in patients infected with COVID-19. These symptoms include nausea, vomiting, anorexia, abdominal pain and diarrhea. The prevalence of data from various studies reporting the presence of diarrhea symptoms in patients infected with COVID-19 is around $1.25 \%$ to $61.32 \%$ with an average of $11.52 \%$. Previous research by Leung et al. (2003) in patients with severe acute respiratory syndrome (SARS) with gastrointestinal symptoms, $20.3 \%$ to $38.4 \%$ had diarrhea symptoms. A 2015 study also showed that $30 \%$ of patients with Middle East respiratory syndrome (MERS) had symptoms of diarrhea. ${ }^{19}$

In this study, patients with severe and critical symptoms had diarrhea symptoms. Based on the results of data analysis, there was a significant relationship between the incidence of diarrhea symptoms and the severity of the degree of COVID-19. This is supported by the meta-analysis research of Ghimmer et al (2021) which shows that the significant severity of COVID-19 infection is found in patients who have diarrhea symptoms $(\mathrm{OR}=1.6)$. Stool examination of COVID-19 patients also showed $48.1 \%$ detectable viral RNA. In addition, as many as $70 \%$ of these positive samples previously had negative results on examination of respiratory samples. ${ }^{20}$

COVID-19 infection occurs due to the binding of the SARS-COV-2 virus with the ACE2 receptor.
These receptors are expressed on AT2 cells of the lung, proximal esophagus, liver and absorptive enterocyte cells from the ileum and colon. ACE-2 expression was higher in type II epitheliat cells in the small intestine, duodenum, and colon than in the lungs. ${ }^{21}$ In addition to ACE2 receptors, SARS-COV-2 also binds to the TMPRSS2 protease in the epithelial of the small intestine. Viral infection causes intestinal permeability to be impaired and eventually enterocyte malabsorption occurs. Activation of the ACE2 receptor will affect the absorption of amino acids in food which will later regulate antimicrobial peptides so that homeostatic microbiome in the intestine is disrupted. This situation causes inflammation of the intestine and the occurrence of diarrhea. ${ }^{3,6}$

The incidence of ARDS in patients with moderate degree of COVID-19 with gastrointestinal symptoms was $6.76 \%$, which was significantly higher than in patients without gastrointestinal symptoms $(2.08 \%)$. The proportion of cases with more severe conditions had gastrointestinal symptoms higher at $25 \%$ among similar cases overall (10.4\%). ${ }^{18}$ In patients with gastrointestinal symptoms such as diarrhea it can cause electrolyte disturbances, especially a decrease in serum sodium levels, especially if nausea is added, vomiting, fatigue, and headaches. ${ }^{18}$ These situations if not treated in a timely manner can lead to coma and circulatory failure. These data suggest that the clinical appearance of COVID-19 patients with significantly more gastrointestinal symptoms has more serious inflammation, more complications and a greater likelihood of severity. ${ }^{18}$

Based on the data analysis test, the incidence of diarrhea has a significant effect on the mortality rate of COVID-19 patients. This is in accordance with the previous results that diarrhea was shown to be related to the severity of the clinical condition of patients infected with COVID-19. The affinity bond between SARS-CoV-2 and the ACE2 receptor was 10-20 times higher than SAR-CoV. Activation of these receptors, especially in the intestinal epithelium, will increase the inflammatory response resulting in impaired permeability and malabsorption in the intestine. This causes diarrhea to get worse. Other gastrointestinal symptoms will usually also appear such as nausea, vomiting, anorexia, malaise, and headache. Gastrointestinal tract disorders that cause damage to the intestinal mucosa and bacterial imbalance will affect the portal vein so that it interferes with the gutliver axis..$^{18}$ Impaired liver function causes damage marked by increased levels of bilirubin, alanine 
aminotransferase, and aspartate aminotransferase. The incidence of patients infected with COVID-19 with symptoms of diarrhea and impaired hepatic function was $17.57 \%$ higher than without symptoms of diarrhea $(8.84 \%) .{ }^{18}$ Diarrhea will also cause dehydration, electrolyte imbalance, which continues with circulatory disorders and is followed by events. ARDS aligned to coma. ${ }^{3}$ Multi-organ damage and worsening of the condition in COVID-19 patients with diarrhea symptoms are thought to increase the mortality rate.

This study uses a case-control research design so it has several weaknesses. Data regarding diet, personal hygiene, and past medical history that also contribute to diarrhea symptoms cannot be evaluated so further research is needed with a cohort design to validate this study. In addition, the management of patients in this study was not evaluated which allowed for differences in patient prognosis, so further studies evaluating the management of COVID-19 patients with diarrhea symptoms are needed.

\section{CONCLUSION}

In this study, there was a relationship between diarrhea symptoms and transminitis, severity and mortality of COVID-19 patients at Saiful Anwar Hospital Malang.

\section{REFERENCES}

1. Setiati S, Azwar MK. COVID-19 and Indonesia. Acta Med Indones 2020;52:84-9.

2. Li H, Burm SW, Hong SH, Ghayda RA, Kronbichler A, Smith L, et al. A comprehensive review of Coronavirus Disease 2019: epidemiology, transmission, risk factors, and international responses. Yonsei Med J 2021;62:1-11.

3. D'Amico F, Baumgart DC, Danese S, Peyrin-Biroulet L. Diarrhea during COVID-19 infection: pathogenesis, epidemiology, prevention, and management. Clin Gastroenterol Hepatol 2020;18:1663-72.

4. Tariq R, Saha S, Furqan F, Hassett L, Pardi D, Khanna S. Prevalence and Mortality of COVID-19 patients with gastrointestinal symptoms: a systematic review and metaanalysis. Mayo Clin Proc 2020;95:1632-48.

5. Villapol S. Gastrointestinal symptoms associated with COVID-19: impact on the gut microbiome. Transl Res 2020;226:57-69.

6. Wang F, Zheng S, Zheng C, Sun X. Attaching clinical significance to COVID-19-associated diarrhea. Life Sci 2020;260:118312.

7. Ghimire S, Sharma S, Patel A, Budhathoki R, Chakinala R, $\mathrm{Khan} \mathrm{H}$, et al. Diarrhea is associated with increased severity of disease in COVID-19: systemic review and metaanalysis. SN Compr Clin Med 2021:1-8.

8. Puli S, Baig M, Walayat S. Gastrointestinal symptoms and elevation in liver enzymes in COVID-19 infection: a systematic review and meta-analysis. Cureus 2020;12:e9999.

9. Hao SR, Zhang SY, Lian JS, Jin X, Ye CY, Cai H, et al. Liver enzyme elevation in Coronavirus Disease 2019: a multicenter, retrospective, cross-sectional study. Am J Gastroenterol 2020;115:1075-1083.

10. Rozenfeld Y, Beam J, Maier H, Haggerson W, Boudreau K, Carlson J, Medows R. A model of disparities: risk factors associated with COVID-19 infection. Int J Equity Health 2020;19:126.

11. Griffith DM, Sharma G, Holliday CS, Enyia OK, Valliere M, Semlow AR, et al. Men and COVID-19: a biopsychosocial approach to understanding sex differences in mortality and recommendations for practice and policy interventions. Prev Chronic Dis 2020;17:E63.

12. Guo YR, Cao QD, Hong ZS, Tan YY, Chen SD, Jin HJ, et al. The origin, transmission and clinical therapies on coronavirus disease 2019 (COVID-19) outbreak - an update on the status. Mil Med Res 2020;71:11.

13. Zhang H, Li HB, Lyu JR, Lei XM, Li W, et al. Specific ACE2 expression in small intestinal enterocytes may cause gastrointestinal symptoms and injury after 2019-nCoV infection. Int J Infect Dis 2020;96:19-24.

14. Chidambaram V, Tun NL, Haque WZ, Majella MG, Sivakumar RK, Kumar A, et al. Factors associated with disease severity and mortality among patients with COVID-19: a systematic review and meta-analysis. PLoS One 2020;15:e241541.

15. Xiao Y, Huang S, Yan L, Wang H, Wang F, Zhou T, et al. Clinical characteristics of diarrhea in 90 cases with COVID-19: a descriptive study. Int Emerg Nurs 2020;52:100912.

16. Zhang LB, Pang RR, Qiao QH, Wang ZH, Xia XY, Wang CJ, et al. Successful recovery of COVID-19-associated recurrent diarrhea and gastrointestinal hemorrhage using convalescent plasma. Mil Med Res 2020;7:45.

17. Chai XQ, Hu LF, Zhang Y, et al. Specific ACE2 expression in cholangiocytes may cause liver damage after SARS-CoV-2 infection. Bio R xiv 2020:4:14.

18. Ye Q, Wang B, Zhang T, Xu J, Shang S. The mechanism and treatment of gastrointestinal symptoms in patients with COVID-19. Am J Physiol Gastrointest Liver Physiol 2020;319:G245-G252.

19. Leung WK, To KF, Chan PK, Chan HL, Wu AK, Lee $\mathrm{N}$, et al. Enteric involvement of severe acute respiratory syndrome-associated coronavirus infection. Gastroenterology 2003;125:1011-7.

20. Cheong J, Bartell N, Peeraphatdit T, Mosli M, Al-Judaibi B. Gastrointestinal and liver manifestations of COVID-19. Saudi J Gastroenterol 2020;26:226-32.

21. Han C, Duan C, Zhang S, Spiegel B, Shi H, Wang W, et al. Digestive symptoms in COVID-19 patients with mild disease severity: clinical presentation, stool viral RNA testing, and outcomes. Am J Gastroenterol 2020;115:916-923. 